\title{
Predictors of Child Labour Among In-School Adolescents in a Rural Local Government Area in Oyo State, Nigeria
}

\author{
Dr. C.A. Adegbenro \\ Dr. O.F. Opasina \\ Dr. F.O. Fehintola \\ Dr. S.A. Olowookere \\ Department of Community Health, \\ Obafemi Awolowo University, Ile-Ife, Nigeria
}

doi: 10.19044/esj.2017.v13n23p193 URL:http://dx.doi.org/10.19044/esj.2017.v13n23p193

\begin{abstract}
Background: Child labour continues to be a daunting challenge worldwide. Child labour contradicts the intrinsic value Africans place on children.

Objective: The study determined the prevalence and predictors of child labour.

Subjects: in-school adolescents aged $10-14$ years

Methodology: This descriptive cross-sectional study design. The data was collected using a pre-tested semi-structured questionnaire on child labour, school attendance, and academic performance. Data were analyzed using descriptive and inferential statistics.

Result: About $31.5 \%$ of the 660 participants had ever been engaged in child labour while $24.2 \%$ were currently engaged. The types of child labour the respondents were involved in included shop trading (85.0\%) and street hawking (76.3\%). Most employers of child labour were parents $(85.0 \%)$ and the majority $(71.3 \%)$ were unpaid. Few respondents involved in child labour had good attendance record (14.2\%) and good academic performance $(10.6 \%)$. The predictors of child labour include mothers lower education $(\mathrm{OR}=8.786,95 \% \mathrm{CI}=3.589-21.508, \mathrm{p}<0.0001)$, having more than three children in the family $(\mathrm{OR}=2.488,95 \% \mathrm{CI}=1.403-4.425, \mathrm{p}=0.002)$ and loss of parents $(\mathrm{OR}=1.7,95 \% \mathrm{CI}=1.059-2.755, \mathrm{p}=0.028)$.

Conclusion: Child labour was prevalent among in-school adolescents. It negatively influences school attendance and academic performance. It is necessary to discourage child labour through community sensitization and improving the socio-economic status of parents.
\end{abstract}


Keywords: Child labour, academic performance, school attendance

\section{Introduction}

Child labour is any human action other than study or play, paid or unpaid, that is carried out by an individual below 15 years (Khalid and Shahnaz, 2001; Suryahadi et al., 2005; Rena, 2009). Child labour includes employing children in any work that deprives them of their childhood, hinders their ability to attend regular school, and that is psychologically, physically, socially or morally dangerous and harmful by its nature or circumstance (Khalid and Shahnaz, 2001; Blunch et al., 2002; Blanchfield, 2013; Sackmen, 2011; Dutta, 2014). Worldwide, children suffer from a multitude of harms, malnutrition, starvation, infectious diseases, congenital defects, abandonment, economic exploitation and the violence of warfare (Brooks-Gunn and Duncan, 1997; Ali and Khan, 2012; Blanchfield, 2013; International Labour Organization, 2013). Worldwide agriculture is the largest employer of child labour. Child labour has become widespread in developing countries, including Nigeria (Khalid and Shahnaz, 2001; Suryahadi et al., 2005; Rena, 2009; Dutta, 2014). Poverty had been noted to be associated with child labour for generations (Khalid and Shahnaz, 2001; Suryahadi et al., 2005; Rena, 2009). For instance, during the transition from agricultural to the industrial revolution in England, child labour became very common in poor families who were not able to cater for themselves and their children leaving these children to fend for themselves (Dutta, 2014).

However, the situation of child labour in Africa before the advent of modernization processes could to a large extent have been an intergenerational non-exploitative culture (Sackmen, 2011). The 1990 United Nations Convention on the Rights of the Child stated that children have a right to basic education and freedom from exploitation (Blunch et al., 2002; Blanchfield, 2013). Factors to consider are the child's age, the hours and work performed, and the conditions that may vary between sectors (Blunch et al., 2002; Ali and Khan, 2012; Blanchfield, 2013; International Labour Organization, 2013).

Child labour has been implicated as the root cause of some problems such as learning disabilities, malnutrition, work-related injuries and mortality (Brooks-Gunn and Duncan, 1997; Ali and Khan, 2012; International Labour Organization, 2013; Ahmed and Ray, 2014). Variants of the problem are endemic in developing countries including Nigeria. The problem of child labour has become a major issue worldwide as it has become the root cause of avoidable death in children in poor regions of the world (Brooks-Gunn and Duncan, 1997; Ahmed and Ray, 2014; Bashir, 2014). Since the recognition of child labour as a global social and health problem, various 
efforts have been made towards controlling it however, the literature shows that it remains predominant with sub-Saharan Africa having the highest prevalence rates of child labour with several African nations having over $59 \%$ of children working (Abubakar, 2009; UNICEF, 2012).

In northern Nigeria, it is customary for boys to receive Islamic education which is similar to the child foster system (Togunde and Carter, 2006; Aghedo and Eke, 2013; Shehu, 2015; Wara, 2015; Usman and Romic, 2015; Gomment, 2017). This Islamic education system promotes the sending of children by their families from rural to urban areas to live with and receive Islamic education from Islamic teachers (Aghedo and Eke, 2013; Shehu, 2015). This has given rise to the emergence of almajiris (child beggars) exploited by their teachers to beg for alms and food (Shehu, 2015; Wara, 2015). Estimates suggest over 10 million children are almajiris (Togunde and Carter, 2006; Wara, 2015; Usman and Romic, 2015; Gomment, 2017). This child foster system enrolled both boys and girls (Togunde and Carter, 2006; Gomment, 2017). These girls are exploited in domestic service, where they risk sexual and physical abuse and there are reports of girls in some Nigerian refugee camps being subjected to prostitution (Togunde and Carter, 2006; Usman and Romic, 2015; Gomment, 2017). Nigeria is a source, transit, and destination country for child trafficking (Abubakar, 2009; Aghedo and Eke, 2013). Children in Nigeria are trafficked internally for work in domestic service, agriculture, street-peddling, and begging (Aghedo and Eke, 2013; Togunde, 2017).

The predictors of child labour are not well studied in Nigeria making it essential to carry out this present study. This study also documents information about its effect on school attendance and academic performance. The findings of this study will contribute to evidence to take decisions regarding interventions to control and eventually eliminate child labour in this traditional African society where there are various cultural and religious barriers against the implementation of child rights.

\section{Methodology}

The study was carried out in Egbeda Local Government Area, Egbeda, Ibadan, Oyo state, Nigeria. Egbeda Local Government, a rural local government area was created in 1989 when it was carved out of Lagelu Local Government. According to the 2006 census, it has an area of $191 \mathrm{~km}^{2}$ and a population of 291,573. It has 76 public and 53 private primary schools, 25 public and 55 private secondary schools, 19 dispensaries and 27 private health facilities.

\section{Study Design}

A cross-sectional descriptive design was used. 
Study Population

Public junior secondary school students aged 10-14 years.

Inclusion Criteria

Students aged 10-14years in selected public junior secondary schools were included in the study.

Sample Size Determination

The Fishers formula for estimating sample size was employed (Kish, 1965).

$$
\mathrm{n}=\frac{\mathrm{Z}^{2} \mathrm{pq}}{\mathrm{d}^{2}}
$$

where: $\mathrm{n}=$ the desired sample size (when population is $>10,000$ )

$\mathrm{Z}=1.96$, the standard normal deviate corresponding to the $95 \%$ confidence interval.

$\mathrm{p}=50 \%=(0.5)$, an estimate of the proportion of children engaged in child labour in Nigeria (Khakshour et al., 2015).

$$
\begin{aligned}
& \mathrm{q}=1-\mathrm{p}=50=(0.5) \\
& \mathrm{d}=\text { degree of accuracy desired }=0.05 \\
& \mathrm{n}=\frac{1.96^{2} \times 0.5 \times 0.5}{0.05^{2}} \\
& \mathrm{n}=\frac{0.9604}{0.0025} \\
& =384.16 \approx 400 \text { (estimated minimum sample size) }
\end{aligned}
$$

Sampling Technique

A multi-stage sampling technique was used to select 660 respondents from the selected junior secondary schools. In the first stage, 10 schools were selected by simple random sampling technique from the 25 public junior secondary schools in the local government area. In the second stage, the respondents in each school were chosen using the proportion of students in classes 1-3 with respect to the total population of students in the 10 selected schools. In the third stage, the classes with different arms (of which one arm) were selected from classes 1-3 of the selected junior secondary schools using the simple random technique (balloting). In the last stage, respondents were selected proportionate to the population size in each class.

\section{Instrument for Data Collection}

Information was obtained from the respondents using a pre-tested, semi structured interviewer-administered questionnaire with questions on socio-demographic characteristics, the pattern of child labour, academic performance and attendance records.

\section{Data collection}

Data were collected by graduate research assistants after being trained in the administration of the instruments. 


\section{Data Analysis}

Completed questionnaire was given a unique code and entered into SPSS version 20. Frequencies of variables were used to check for missed values and outliers. Any error identified at this time was corrected. The use of descriptive statistics was employed to determine frequency distribution and measures of central tendency and dispersion. Chi -square was carried out to establish relationships between child labour, academic performance, and school attendance. Bivariate logistic regression analysis showing predictors of current engagement in child labour was done. Statistical significance level was set at $\mathrm{p}<0.05$.

\section{Ethical Consideration}

Ethical clearance was obtained from the Research and Ethics Committee of the Institute of Public Health, Obafemi Awolowo University, Ile-Ife, Nigeria. Permission was taken from the head of the selected schools to carry out this study, the Local Government Area and the State Ministry of Education. Written informed consent was obtained from the parents and assent from the respondents.

\section{Results}

A total of 660 in-school adolescents age 10-14 years with completed questionnaire were analyzed. Most (63\%) were aged between 13-14 years with mean age (SD) of 12.7 (1.1) years. About 55\% were females, 91.5\% were from monogamous while only $8.5 \%$ are from polygamous families. Ninety-three percent revealed that their parents were alive and $84.6 \%$ lived with them (Table 1).

Table 1: Demographic characteristics of respondents $\quad \mathrm{N}=660$

\begin{tabular}{|c|c|c|}
\hline Variable & Frequency & $\%$ \\
\hline Age & & \\
$10-12$ years & 244 & 37.0 \\
13-14 years & 416 & 63.0 \\
\hline Sex & 364 & 55.2 \\
Female & 296 & 44.8 \\
Male & 636 & 96.4 \\
\hline Tribe & 18 & 2.7 \\
Yoruba & 6 & 0.9 \\
Ibo & 34 & 5.2 \\
Hausa & 56 & 8.5 \\
None & 328 & 49.7 \\
Primary & 242 & 36.6 \\
Secondary & & \\
Tertiary & & \\
\hline Mothers' level of education & & \\
\hline
\end{tabular}




\begin{tabular}{|c|c|c|}
\hline Parents' Religion & 536 & 81.2 \\
Christianity & 124 & 18.8 \\
Islam & & \\
\hline Parents' Marriage Type & 91.5 \\
Monogamy & 56 & 8.5 \\
Polygamy & 86 & 13.0 \\
No of children in the family & 484 & 73.3 \\
1-3 & 90 & 13.7 \\
$>6$ & & \\
& & \\
Parent (s) alive & 612 & 32.7 \\
Both & 20 & 2.0 \\
Mother & 18 & 1.5 \\
Father & 10 & 84.6 \\
None & & 10.6 \\
Family living with & 558 & 1.2 \\
Both parents & 70 & 3.6 \\
Mother & 8 & \\
Father & 24 & \\
Relative & & \\
\hline
\end{tabular}

About $31.5 \%$ of the respondents had ever engaged in child labour, while $24.2 \%$ were currently engaged in child labour as at the time of the study. This gave a prevalence of $24.2 \%$. The mean age at which they started work was 9.32 (1.3) years. Also, $78.8 \%$ of them worked during weekdays while $76.3 \%$ felt too young or tired for the work assigned. Reasons for involvement in child labour were mainly economic. This includes attempt by respondent to sponsor their schooling $(87.5 \%)$ or vocational training $(83.8 \%)$ and support household income (30.0\%) (Table 2)

Table 2: Occurrence of child labour among in-school adolescents

\begin{tabular}{|c|c|c|}
\hline Variable & Frequency & Percentage (\%) \\
\hline Ever engaged in Child labour & & \\
Yes & 208 & 31.5 \\
No & 452 & 68.5 \\
Total & 660 & 100 \\
\hline Currently engaged in child labour outside & & \\
school/home & 160 & 76.9 \\
Yes & 48 & 23.1 \\
No & 208 & 100 \\
Total & 12 & 7.5 \\
\hline 9o (in currently engaged) & 94 & 58.8 \\
\hline Age at which work started & 34 & 21.2 \\
*Period of Work & 126 & 78.8 \\
Weekends(only) & 116 & 72.5 \\
Weekdays/weekends & 116 & \\
Holidays & & \\
Festive period & & \\
\hline
\end{tabular}




\begin{tabular}{|c|c|c|}
\hline Feel too young/tired for type of work & 122 & 76.3 \\
Yes & 18 & 11.2 \\
No & 20 & 12.5 \\
Not Sure & 160 & 100 \\
Total & 140 & \\
*Reasons for engaging in labour & 134 & 87.5 \\
To sponsor schooling & 48 & 30.0 \\
\hline Learn vocational skills/apprenticeship & & \\
To support household income (cash/kind) &
\end{tabular}

*Multiple responses

Table 3 shows that $85 \%$ of the children work for their parents with the majority not receiving any payment for work done (71.3\%). Eighty-eight percent revealed that their parents or guardians received their payment for work. The majority of respondents $(75 \%)$ were exposed to harmful objects and danger while at work.

Table 3: Employer of labour and type of child labour

\begin{tabular}{|c|c|c|}
\hline Variables & frequency & percentage \\
\hline Employer & & \\
\hline Parents & & 85.0 \\
\hline Yes & 136 & 15.0 \\
\hline No & 24 & \\
\hline Agent & & 15.0 \\
\hline Yes & 24 & 85.0 \\
\hline No & 136 & \\
\hline Paid for work & & \\
\hline Yes & 34 & 21.2 \\
\hline No & 114 & 71.3 \\
\hline Not sure & 12 & 7.5 \\
\hline If paid who received payment & & \\
\hline Parent/Guardian & 30 & 88.3 \\
\hline Agent & 2 & 5.8 \\
\hline self & 2 & 5.9 \\
\hline How money is spent & & \\
\hline School fees & 20 & 58.8 \\
\hline House keep & 14 & 41.2 \\
\hline Satisfied with payment & & \\
\hline Yes & 10 & 29.4 \\
\hline No & 24 & 70.6 \\
\hline *Type of labour & & \\
\hline Trading in shop & 136 & 85.0 \\
\hline Hawking/street & 122 & 76.3 \\
\hline peddling/Vending & 32 & 20.0 \\
\hline Farm work & 24 & 15.0 \\
\hline Domestic services & 26 & 16.3 \\
\hline Apprenticeship & 2 & 1.3 \\
\hline Begging & & \\
\hline $\begin{array}{l}\text { Exposure to danger and harmful } \\
\text { objects }\end{array}$ & & \\
\hline Yes & 120 & 75.0 \\
\hline No & 40 & 25.0 \\
\hline
\end{tabular}




\begin{tabular}{|c|c|c|}
\hline *Exposure to harmful objects at & & \\
work & 116 & 72.5 \\
Severe weather & 18 & 11.3 \\
Cuts /burns & 94 & 58.8 \\
Vehicular accidents & 14 & 8.8 \\
Accidents from heavy load & 10 & 6.3 \\
Theft & 10 & \\
\hline
\end{tabular}

*Multiple responses

There was a statistically significant relationship between child labour and number of children in the family, parents alive and mothers' level of education $(\mathrm{p}<0.05)$. There was a significant relationship between child labour and irregular school attendance, and poor academic performance $(\mathrm{p}<0.05)$ as shown in Table 4.

Table 4: Association between Respondents' Socio-demographic characteristics, school attendance, academic performance and child labour

\begin{tabular}{|c|c|c|c|c|}
\hline \multirow[t]{2}{*}{ Variable } & \multicolumn{2}{|c|}{$\begin{array}{c}\text { Currently engaged in Child } \\
\text { labour }\end{array}$} & \multirow[t]{2}{*}{$\chi^{2}$} & \multirow[t]{2}{*}{ p-value } \\
\hline & $\begin{array}{c}\text { Yes } \\
\mathrm{n}(\%)\end{array}$ & $\begin{array}{l}\text { No } \\
\mathrm{n}(\%)\end{array}$ & & \\
\hline $\begin{array}{l}\text { Number of children in the family } \\
\qquad \begin{array}{c}1-3 \\
>3 \\
>6\end{array}\end{array}$ & $\begin{array}{c}8(9.3) \\
152(26.4) 8) 8\end{array}$ & $\begin{array}{c}78(90.7) \\
422(73.6)\end{array}$ & 12.02 & 0.001 \\
\hline $\begin{array}{c}\text { Parent(s)alive } \\
\text { Both } \\
\text { Mother } \\
\text { Father } \\
\text { None } \\
\end{array}$ & $\begin{array}{c}125(20.4) \\
8(40) \\
2(11.1) \\
7(70) \\
\end{array}$ & $\begin{array}{c}487(79.6) \\
12(60) \\
16(88.9) \\
3(30) \\
\end{array}$ & 19.55 & 0.0006 \\
\hline $\begin{array}{c}\text { Highest level of education } \\
\text { Mother } \\
<\text { Secondary school } \\
\geq \text { Secondary school }\end{array}$ & $\begin{array}{l}70(77.8) \\
90(15.8)\end{array}$ & $\begin{array}{c}20(22.2) \\
480(84.2)\end{array}$ & 162.6 & $<0.0001$ \\
\hline $\begin{array}{l}\text { School attendance } \\
\text { Regular } \\
\text { Irregular }\end{array}$ & $\begin{array}{l}70(14.2) \\
90(54.2)\end{array}$ & $\begin{array}{c}424(85.8) \\
76(45.8)\end{array}$ & 108.49 & $<0.0001$ \\
\hline $\begin{array}{c}\text { Academic Performance } \\
\text { Good } \\
\text { Average } \\
\text { Poor }\end{array}$ & $\begin{array}{c}5(10.6) \\
124(24.2) \\
31(31.4)\end{array}$ & $\begin{array}{c}42(89.4) \\
390(75.8) \\
68(68.6)\end{array}$ & 7.43 & 0.024 \\
\hline
\end{tabular}

Table 5 above showed that mothers of respondents who had less than secondary school education were nine times more likely to involve their child in child labour compared to their counterparts who had secondary or higher level of education $(\mathrm{CI}=3.589-21.508, \mathrm{p}<0.0001)$. Respondents whose family had more than three children were 2.5 times more likely to be involved in child labour than those with $\leq 3$ children $(\mathrm{CI}=1.403-4.425$, $\mathrm{p}=$ 0.002). Respondents whose parents were not alive were twice more likely to 
be involved in child labour than those whose parents were alive $(\mathrm{CI}=1.059$ 2.755, $\mathrm{p}=0.028$ ).

Table 5: Bivariate logistic regression analysis showing predictors of current engagement in

\begin{tabular}{|c|c|c|c|}
\hline Variables & OR & $95 \%$ CI & p value \\
\hline $\begin{array}{c}\text { Mothers Education } \\
\text { < Secondary school } \\
\text { Secondary school(ref) }\end{array}$ & 8.786 & $3.589-21.508$ & $<0.0001$ \\
\hline $\begin{array}{c}\text { No of Children in the } \\
\text { family } \\
1-3 \text { (ref) } \\
>3\end{array}$ & 2.488 & $1.403-4.425$ & 0.002 \\
\hline $\begin{array}{c}\text { Parent marriage type } \\
\text { Monogamy(ref) } \\
\text { Polygamy }\end{array}$ & 1.62 & $1.034-6.267$ & 0.073 \\
\hline $\begin{array}{c}\text { Parents alive } \\
\text { Yes(ref) } \\
\text { No }\end{array}$ & 1.7 & & 0.028 \\
\hline
\end{tabular}

\section{Discussion}

This study reported the predictors of child labour as poorly educated mothers, large family and the children being orphans. It also reported that children engaged in child labour have poor school attendance and academic performance. This finding corroborated previous studies (Orazem and Gunnarsson, 2003; Ray, 2006; Barnetson, 2009; Malik et al., 2012; Mahmod et al., 2016; Abdullahi et al., 2016). Therefore, it is necessary to ensure that basic education is provided to all women especially those with low socioeconomic status. Child labour contradicts the intrinsic value Africans place on children and it is purely an aberration which takes away the innocence of millions of children and a threat to the future of the country, rather than being an accepted way of life among Africans.

The prevalence of the respondents engaged in child labour is unacceptably high, although, it correlates with International labour organization's global estimate of $25.8 \%$ of 10-14year old engaged in child labour in Africa (Fetuga et al., 2005). Also, more females than males engaged in child labour. Previous studies have reported varying proportion of children engaged in child labour with most studies reporting that more females than males working (Togunde and Carter, 2006; Rena, 2009; Malik et al., 2012; Mahmod et al., 2016; Abdullahi et al., 2016). In this study majority of child labourers were from families with more than 3 children. This might be due to the fact that families with more children are more likely to send their children to work in order to earn income for the family as such families are confronted with increasing cost of social services or nonavailability of social amenities. This finding corroborated that of previous 
studies on child labour (Ray, 2006; Malik et al., 2012; Mahmod et al., 2016; Abdullahi et al., 2016).

The majority of child labourers in this study worked for their parents which agree with previous studies that children were predominantly employed by their parents, rather than factories (Abubakar, 2009; Edet, 2013; Gomment, 2017). Many of the working respondents did it to partly sponsor their schooling and learn vocational skills. This was similar to the findings that one-third of children who were involved in child labour do so for themselves or for their family's livelihood (UNICEF, 2012; Edet, 2013).

The majority of child labourers in this study were involved in petty trading in shops and street hawking. This was contrary to the findings of previous studies that reported agriculture as the largest employer of child labourers, and that it alone employs more than $30 \%$ of all African children aged 10-14years (Blunch et al., 2002; International Labour Organization, 2013; Edet, 2013). This disparity might be due to the fact that most families now engage in selling rather than farming.

The highest percentage of the child labourers mothers had lower education. Child labour has been linked with the literacy level of mothers in that they are likely to place less value on children education especially girls who are believed to end their career in their husbands' homes. This was similar to the findings of previous studies that reported that school attendance is better when mothers have higher education (Ray, 2006; Mahmod et al., 2016; Abdullahi et al., 2016).

Every child is supposed to fully concentrate on academic matters and play rather than work. This study reported that majority of the children worked on weekdays when they are meant to be in classes learning or attending to their studies. This shows the level of societal impoverishment because rather than parents taking care of their children, the parents now expect the children as young as they are to fend for the family or augment the family's income. Therefore, it is not surprising that the children engaged in child labour had poorer academic performance and poorer school attendance when compared with children that were not involved in child labour. This was similar to findings of previous studies that work has a detrimental effect on learning achievements and school attendance (Togunde and Carter, 2006; Ray, 2006; Malik et al., 2012; Khakshour et al., 2015; Mahmod et al., 2016; Abdullahi et al., 2016). The predictors of child labour identified in this study were mothers low level of education, more than three children in the family and parents being dead. Studies done in the past have revealed mothers' low level of education and having many children strongly predicts engagement in child labour (Malik et al., 2012; Shehu, 2015). This could be because large families are less likely to have adequate resources for all the family members and this might result in the need to send out children 
to boost the family financial resources. Mothers with a low level of education are likely to be unemployed or underemployed this might also results in sending their children to work. Loss of one or both parents could predispose a child to be involved in child labour as most relatives may not have adequate resources or willing to take care of these children.

The study is limited by its cross-sectional study design which measures the exposure and outcome at the same time, and cannot measure the cause and effect relationship. Also, the responses are self-reported. However, research assistants were well trained to ensure proper reporting while respondents were well informed about the purpose of this study.

\section{Conclusion}

In conclusion, the prevalence of child labour among these children is unacceptably high with it more common among children with poorly educated mothers, those in large families and those who are orphans. These children work to augment their family's income and partly sponsor themselves. Child labour negatively affects their school attendance and academic performances in this study. All efforts should be put in place by policy makers to reduce and eventually eliminate child labour through proper health promotion and re-enactment of laws protecting the rights of children.

\section{References:}

1. Abubakar A. (2009). Nigeria struggles to curb rise in child beggars. The Telegraph;18.

2. Abdullahi I.I., Noor Z.M., Said R., Baharumshah A.Z. (2016). Does poverty inflate the prevalence of child labour in developing countries? International Journal of Economics and Financial Issues. 6(1): 7-12.

3. Aghedo I., Eke S.J. (2013). From Alms to arms: The Almajiri phenomenon and internal security in Northern Nigeria. The Korean Journal of Policy Studies. 28(3): 97-123

4. Ahmed S., Ray R. (2014). Health consequences of child labour in Bangladesh. Demographic research. 30(4): 111-150.

5. Ali H., Khan S. (2012). The overcoming of child labour in India: In perspective of constitutional and legislative framework. Journal of Business Management and Social Sciences Research. 1(3): 83-91.

6. Barnetson B. (2009). Regulation of child and adolescents employment in Alberta. Just Labour: A Canadian Journal of work and society. 13: 29-47.

7. Bashir Z. (2014). Child labour in India: causes and interventions. International Journal of Scientific Research and Education. 2(10): 2160-2164. 
8. Blanchfield L. (2013). The United Nations Convention on the Rights of the Child. Congressional Research Service Accessed September 30, 2013.

9. Blunch N.H., Dar A., Kim B., Sasaki M. (2002). Participation of children in schooling and labour activities: a review of empirical studies. Social Protection Discussion Paper Series. No. 0221. Washington DC, World Bank.

10. Brooks-Gunn J., Duncan G.J. (1997). The effect of poverty on children. The future of children. 7(2): 55-71.

11. Dutta A. (2014). Children in Dickens's novels. International Journal on Studies in English language and literature. 2(2): 1-4.

12. Edet GE, Etim N-AA. (2013). Child labour in agriculture among poor rural households: some issues and facts. European Journal of Physical and Agricultural Sciences. 1(1):1-7.

13. Fetuga BM, Njokama FO, Olowu AO. (2005). Prevalence, types and demographic features of child labour among school children in Nigeria. BMC international health and human rights. 5(1):2.

14. Gomment T.I. (2017). Parental neglect and juvenile delinquency of Almajirai in Kano State, Nigeria. Imperial Journal of interdisciplinary Research. 3(1): 1237-1242.

15. International Labour Organization. (2013). Marking progress against child labour: Global estimates and trends 2000-2012. International Labour Organization Geneva.

16. Khakshour A, Ajilian Abbasi M, Seyedi SJ, Saeidi M, Khodaee GH. (2015) Child Labour Facts in the Worldwide: A Review Article. International Journal of Pediatrics. 3(1.2):467-73.

17. Khalid U., Shahnaz L. (2001). Socio-economic conditions of child labourers in Pakistan: Evidence from the Labour Force Survey. The Labour Journal of Economics. 9(1): 85-104

18. Kish L. (1965). Survey sampling. John Willey \& Sons, New York.

19. Mahmod N., Salleh M., Muhammad A., Mohd A. (2016). A study of child labour as a form of child abuse in Malaysia. International Journal of Social Sciences and Humanity. 6(7): 525-530.

20. Malik A.K., Bhutto N.A., Shaikh D., Akhter E., Butt F. (2012). Another real fact about child labour: A comparative study between districts of two provinces of Pakistan. Proceedings of the second international conference on business management. 1-35.

21. Orazem P.F., Gunnarsson V. (2003). Child labour, school attendance, academic performance: A review. International Labour Organization/International programme on the elimination of child labour working paper. 1-24. 
22. Ray R. (2006). Education and child labour: a global perspective. Utas school of economics and finance discussion paper 2006-05. 1-19.

23. Rena R. (2009). The child labour in developing countries: a challenge to millennium development goals. Indus Journal of Management and Social Sciences. 3(1): 1-8.

24. Sackmen FD. (2011). Modernization Processes and Child Labour in Central Africa. Norway: Oslo University College.

25. Shehu S. (2015). The impact of boko haram on Nigerian national development. Proceedings of International conference on empowering Islamic civilization in the $21^{\text {st }}$ century. 40-50.

26. Suryahadi A., Priyambada A., Surmato S. (2005). Poverty, school, and work: children during the economic crisis in Indonesia. Development and change. 36(2): 351-373.

27. Togunde D., Carter A. (2006). Socio-economic causes of child labour in urban Nigeria. Journal of Children and Poverty. 12(1): 73-89.

28. UNICEF. (2012). Percentage of children aged 5-14 engaged in child labour.

29. Usman A., Romic A. (2015). A proposed framework of unemployment and youth restiveness in the north-eastern Nigeria: Exploring the role of 'Almajiri' culture. Ausralian Journal of Basic and Applied Sciences. 9(14): 45-52.

30. Wara M.A. (2015). The metamorphosis of roving-studentship (Yawon Almajiranci): An Islamic historical challenge of the $21^{\text {st }}$ century experience in northern Nigeria. International Journal of History and Cultural Studies. 1(2): 36-40. 